\title{
Effect of late prepartum fibre-based diets on the live weight changes and reproduction of Holstein cows in the subsequent lactation period
}

\author{
B.A. Useni ${ }^{1 \#}$, C.J.C. Muller ${ }^{1,2} \&$ C.W. Cruywagen ${ }^{1}$ \\ ${ }^{1}$ Department of Animal Sciences, University of Stellenbosch, Private Bag X1, Matieland 7602, South Africa; ${ }^{2}$ Western Cape \\ Department of Agriculture, Research and Technology Development Services, Directorate: Animal Sciences, Private bag X1, \\ Elsenburg 7607, South Africa
}

(Received 26 February 2018; Accepted 2 September; First published online 7 March 2019)

\author{
Copyright resides with the authors in terms of the Creative Commons Attribution 4.0 South African License. \\ See: http://creativecommons.org/licenses/by/4.0/za \\ Condition of use: The user may copy, distribute, transmit and adapt the work, but must recognize the authors and \\ the South African Journal of Animal Science
}

\begin{abstract}
The objective of this study was to evaluate two late prepartum fibre-based diets that differed in nonstructural carbohydrate (NFC) and protein levels on live weight (LW) changes and fertility traits of Holstein cows until 120 days postpartum. At 30 days before calving, 120 pregnant Holsteins (heifers, $n=54$ and dry cows, $\mathrm{n}=66$ ) from the Elsenburg herd were assigned to two nutritional treatments according to parity, expected calving date, LW, and milk production during the previous lactation. Prepartum heifers and cows were fed independently a similar type and level of a prepartum concentrate, associated with an ad libitum intake of either unchopped oat hay for the control group or a partial total mixed ration (pTMR: oat hay (48\%), lucerne hay (43\%) and soybean oil cake meal (9\%)) for the treatment group. After parturition, cows in both the control and treatment groups were maintained on ad libitum cultivated irrigated kikuyu-ryegrass pastures, supplemented each with a post-partum concentrate of $7 \mathrm{~kg} /$ day from calving until 120 days in milk (DIM). As expected, young and still growing primiparous cows were significantly lighter in pre- and post-partum LW traits compared with mature multiparous cows (parity $>3$ ). Prepartum LW of cows was similar between the control and the treatment in both parity groups. Post-partum LW of the primiparous cows differed significantly between the control and the treatment, which were $488 \pm 9$ and $507 \pm 13 \mathrm{~kg}$, respectively. However, no difference was observed in terms of post-partum LW of multiparous cows of the control and the treatment groups, which were $579 \pm 10$ and $579 \pm 8$ $\mathrm{kg}$, respectively. Primiparous cows that received the prepartum oat hay-based diet showed significant decrease

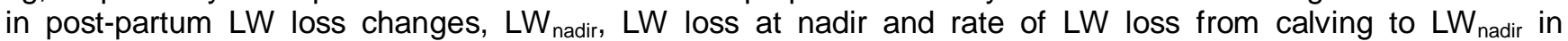
comparison with their counterparts on the prepartum pTMR-based diet, but these LW traits were similar in multiparous cows. Prepartum diets did not have an effect on post-partum fertility parameters of the multiparous cows, whereas primiparous cows that received the control diet recorded a significantly longer interval from calving to first service (CFS) in the subsequent lactation in comparison with their counterparts fed the treatment diet i.e. $117 \pm 9$ and $86 \pm 8$ days, respectively. Proportions of cows that were pregnant at 120 DIM were similar in the subsequent lactation between groups that received the prepartum oat hay- and pTMR-based diets in both parity groups. Further research is required to investigate different prepartum feeding periods and nutritional approaches involving various levels and sources of energy and protein nutrients to encourage post-partum metabolic and hormonal responses that benefit the fertility of dairy cows in the subsequent lactation.
\end{abstract}

Keywords: Dairy, dry period, non-structural carbohydrate, protein, postpartum, pregnancy

\# Corresponding author: alainub83@gmail.com

\section{Introduction}

During the transition period, periparturient cows mobilize their stored body reserves in an attempt to meet the increased demands for maintenance and production (i.e. pregnancy growth before calving or milk production 
after calving) (Wankhade et al., 2017). This condition is caused by the periparturient decline in dry matter intake (DMI), which creates a shortage in needed nutrients (glucose, amino acids, fatty acids) and a state of negative energy balance (NEB). NEB, as evidenced by live weight (LW) loss after calving, is a physiological adaptation that occurs in mammals during the periparturient period (Jorritsma et al., 2003). It has been demonstrated that weighing animals regularly is a proxy to identify the energy balance (EB), nutritional status and physiological wellbeing of each cow in the herd in response to managerial purposes (e.g. nutritional treatment according to desired EB balance, LW loss or gain, health status, productivity and reproductive performances) (Alawneh et al., 2012). This technique is an easy and fast method to use at farm level, compared with the inherent difficulties with body condition score (BCS) measurement owing to inter-observer inconsistency and bias (Van Straten et al., 2008). In addition, BCS is not sensitive enough to detect differences in visceral fat deposition, which can affect metabolism and peripartal health compared with continuous LW monitoring (Drackley et al., 2014).

In dairy cows, optimal prepartum dietary management strategies regarding in particular the types and levels of intake of nutrients relative to their requirements are still inconclusive (Janovick \& Drackley, 2010). Rabelo et al. (2005) indicated that feeding high energy levels, which are starch- or fat-based on an ad libitum basis to prepartum cows was beneficial to transition success. On the other hand, an overconsumption of energy in prepartum cows was reported to be detrimental to rumen health and liver function (Grum et al., 1996; Rukkwamsuk et al., 1999) and to decrease DMI (Olsson et al., 1998), all together leading to poor adaptation to NEB in the subsequent lactation. Consequently, feeding prepartum fibre-based diets ( $>400 \mathrm{~g} / \mathrm{kg}$ of NDF on DM basis) containing low digestible energy levels were investigated in dairy cows (Jouany, 2006; Janovick et al., 2011). These researchers reported that such prepartum diets adjusted the DMI to optimise rumen digestion and fermentation, decreased the mobilization of body reserves, and prevented the hepatic deposition of total lipid and tri-acyl glycerol. Furthermore, feeding fibre-based diets that contained low digestible energy levels to dry cows has several benefits in dairy herds, as is evident in fewer health complications, reduced body condition loss, and enhanced reproductive axis after parturition (Beever, 2006; Duffield et al., 2009). The assumption of this study was that improving the late prepartum intake of energy and protein per $\mathrm{kg}$ on a DM basis to enhance the EB status of dairy cows can limit the LW loss and improve fertility during the following lactation. The objective of the study was thus to evaluate the effects of two late prepartum fibre-based diets that differed in levels (low versus high) of NFC and protein on LW changes and fertility traits of Holstein cows until 120 days postpartum.

\section{Materials and Methods}

The ethical clearance for this study was obtained from the Western Cape Department of Agriculture (WCDA)) Project AP/BR/D/CM31). The study investigated the effect of two late prepartum fibre-based diets that differed in levels (low versus high) of NFC and protein on milk production, LW changes and reproduction performances of Holstein cows until 120 days postpartum. In the current manuscript, the results of the prepartum fibre-based diets on the LW changes and reproductive traits of dairy cows are presented.

The study was conducted at Elsenburg Research Farm, WCDA, located approximately $50 \mathrm{~km}$ east of Cape Town at an altitude of $177 \mathrm{~m}$, longitude of $18^{\circ} 50^{\prime}$ and latitude of $33^{\circ} 51^{\prime}$ in the winter rainfall region of South Africa. The area receives an average annual rainfall of $650 \mathrm{~mm}$ and has a typical Mediterranean climate with short cool wet winters and long warm dry summers.

Fresh drinking water was freely available at all times in the trial. Holstein heifers and cows that were expected to calve from February 2014 to July 2015 were used in the study, which took place from 30 days before the expected calving dates to 120 days after calving. A number of 120 pregnant Holsteins (heifers, $n=54$ and dry cows, $n=66$ ) was allocated to two prepartum nutritional compounds according to expected calving date, parity, LW and milk production during the previous lactation. The animal intakes in the trial were done in blocks of two to four cows that had the predicted calving dates within a week. This was to expose them to similar environmental conditions during the post-partum observation period of the trial. Heifers were assigned based on their LW and expected calving dates. The LW of heifers at 30 days prepartum was $538 \pm 9 \mathrm{~kg}$ and $544 \pm 7 \mathrm{~kg}$ for the control and treatment groups, respectively. Primiparous cows were $2.19 \pm 0.05 \mathrm{~kg}$ and $2.24 \pm 0.07$ years old at calving for the control and treatment groups, respectively. Dry cows were assigned according to parity, expected calving date and milk yields in the previous lactation. Live weights of dry cows at 30 days prepartum were $630 \pm 7 \mathrm{~kg}$ and $626 \pm 5 \mathrm{~kg}$ for the control and treatment groups, respectively. The milk yields during the previous lactation of multiparous cows were $8697 \pm 131 \mathrm{~kg}$ and $8650 \pm 132 \mathrm{~kg}$ for the control and treatment groups, respectively. Multiparous cows were $5.41 \pm 0.36$ and $5.11 \pm 0.28$ years old at calving for the control and treatment groups, respectively. 
The chemical compositions of feeds and prepartum diets used in the study are presented in Table 1. Representative samples of feeds used in the current study were collected weekly, then bulked monthly and analysed for chemical composition. AOAC (1990) official methods were used to determine dry matter (DM), ash, fat as ether extract and crude protein (CP) (nitrogen, Nx6.25) contents of feedstuffs and pastures. Neutral detergent fibre (NDF) was determined according to Van Soest et al. (1991), with the use of sodium sulphite anhydrous and amylase to decrease contaminations of nitrogen and starch in the NDF determination. Calcium and $P$ were determined using an inductively coupled plasma dry ashing method (ALASA, dry ashing 6.1.1, RevA/98) with an Iris Advantage Thermo elemental instrument, according to Giron (1973). The NFC in the prepartum diets, which consisted of starches, sugars, organic acids, and other reserve carbohydrates such as fructans, was estimated according to NRC (2001) as follows:

$$
\mathrm{NFC} \text { in } \mathrm{g} / \mathrm{kg} \text { on DM basis }=\mathrm{DM} \times[100-(\mathrm{NDF} \%+\mathrm{CP} \%+\mathrm{Fat} \%+\text { Ash\%) }] / 100 \text {, }
$$

where: DM was expressed in $\mathrm{g} / \mathrm{kg}$; and

NDF, CP, fat and ash were all expressed in \% on DM basis.

Table 1 The chemical composition of feeds and estimated chemical composition of prepartum diets used in the study

\begin{tabular}{|c|c|c|c|c|c|c|c|c|c|}
\hline \multirow[b]{3}{*}{ Parameters } & \multirow[b]{3}{*}{$\begin{array}{l}\text { Oat } \\
\text { hay }\end{array}$} & \multirow[b]{3}{*}{ pTMR $^{2}$} & \multirow[b]{3}{*}{ Pasture } & & & \multicolumn{4}{|c|}{ Prepartum diets ${ }^{3}$} \\
\hline & & & & \multicolumn{2}{|c|}{ Concentrates } & \multicolumn{2}{|c|}{30 to 14 days } & \multicolumn{2}{|c|}{13 days to calving } \\
\hline & & & & $\begin{array}{c}\text { Dry } \\
\text { period }\end{array}$ & Postpartum & Control & Treatment & Control & Treatment \\
\hline $\mathrm{DM}^{1}$ & 932 & 917 & 210 & 891 & 894 & 923 & 911 & 915 & 906 \\
\hline Ash $^{1}$ & 41 & 69 & 103 & 106 & 72 & 55 & 78 & 69 & 84 \\
\hline $\mathrm{CP}^{1}$ & 48 & 152 & 184 & 188 & 179 & 78 & 160 & 107 & 167 \\
\hline Fat as $\mathrm{EE}^{1}$ & 16 & 19 & 34 & 36 & 42 & 20 & 23 & 24 & 26 \\
\hline$N^{\prime} F^{1}$ & 689 & 500 & 539 & 179 & 200 & 580 & 432 & 472 & 368 \\
\hline$N F C^{1}$ & - & - & - & - & - & 247 & 282 & 299 & 322 \\
\hline $\mathrm{Ca}^{1}$ & 3 & 5 & 5 & 29 & 14 & 9 & 10 & 14 & 15 \\
\hline$P^{1 c}$ & 2 & 3 & 5 & 7 & 7 & 3 & 4 & 4 & 5 \\
\hline
\end{tabular}

${ }^{1}$ DM: dry matter in g/kg as is; ash in g/kg DM; CP: crude protein in g/kg DM; EE: ether extract in g/kg DM; NDF: neutral detergent fibre in g/kg DM; NFC: non-fibre carbohydrates in g/kg DM; Ca: calcium in g/kg DM; P: phosphorus in g/kg DM ${ }_{3}^{2}$ pTMR: partial total mixed ration

${ }^{3}$ Determined from the chemical composition of feeds at an estimated intake level of $14 \mathrm{~kg} / \mathrm{cow}$ per day and $12 \mathrm{~kg} / \mathrm{heifer}$ per day on DM basis, respectively

During the dry period (DP), pregnant heifers and dry cows were walked in the morning (08:00) to the individual feeders where they were fed the same level and type of prepartum concentrate and later returned to their own prepartum nutritional compounds where they received an ad libitum intake of unchopped oat hay for the control group and a pTMR for the treatment group. The pTMR consisted of $48 \%$ oat hay $+43 \%$ lucerne hay and $9 \%$ soybean oil cake meal. The prepartum concentrate, which contained maize as the main energy source and anionic salts, was given at $3 \mathrm{~kg} /$ day for heifers and cows from 30 to 14 days prepartum and then from 13 days prepartum to calving at $6 \mathrm{~kg} /$ day and $5 \mathrm{~kg} /$ day for cows and heifers, respectively. Levels of prepartum diets were estimated on a DM basis at $14 \mathrm{~kg} / \mathrm{cow}$ per day and $12 \mathrm{~kg} / \mathrm{heifer}$ per day. The prepartum treatment was formulated to improve prepartum intake of energy and protein per $\mathrm{kg}$ on a DM basis, compared with the control (Table 1). Such improvement in nutrient contents was to optimize the ruminal digestion and fermentation, reduce the extent and the duration of the periparturient NEB, and improve fertility in the subsequent lactation. Following parturition, any health problem was monitored during the first 10 DIM and treated according to the required standard operating procedures by the herd manager after milking sessions or the veterinarian at the weekly visits to the farm, to ensure a return to a normal reproductive health by $30 \mathrm{DIM}$. In addition, cows in both the 
control and treatment groups were maintained postpartum under similar feeding and management conditions. All animals had ad libitum access to cultivated kikuyu-ryegrass pastures, which were irrigated as required, using a permanent irrigation system. Pastures (201 g/kg DM with 539, 34, $184 \mathrm{~g} / \mathrm{kg} \mathrm{NDF,} \mathrm{fat,} \mathrm{CP,} \mathrm{on} \mathrm{a} \mathrm{DM} \mathrm{basis)} \mathrm{(Table}$ 1) were grazed in rotation, ensuring unrestricted DMI under typical farming conditions. Regardless of parity, cows were each supplemented with a post-partum concentrate of $7 \mathrm{~kg} /$ day from calving until 120 days. After each milking session (at 05:30 and 15:00), cows were independently fed half of the daily allowance of concentrate. Using the CPM-Dairy software programme (2006), the post-partum diet was estimated at an intake level of 22 and $25 \mathrm{~kg} \mathrm{DM} /$ day for primiparous and multiparous cows, respectively. The diet consisted of 7 $\mathrm{kg} / \mathrm{animal}$ per day of post-partum concentrate, which was offered in the milking parlour, and the rest of the intake was supplied by the pastures, to provide in total $38 \mathrm{~g} / \mathrm{kg} \mathrm{DM}, 2.47 \mathrm{Mcal} / \mathrm{kg}$ of metabolizable energy, and 454, 40, 183 and $255 \mathrm{~g} / \mathrm{kg}$ of NDF, fat, CP and NFC on a DM basis, respectively.

During the prepartum period, pregnant heifers and dry cows were weighed once every week until parturition. Calving seasons were summer from 15 October to 14 April, with December to February being the hottest months, and winter from 15 April to 14 October, with June to August being the coldest months. Postpartum LW of dairy cows was automatically recorded daily after milking sessions using a calibrated electronic scale. Daily LW data were averaged to weekly means. The nadir was defined as the DIM in which the lowest post-partum LW value was recorded (Sakaguchi, 2009). The post-partum weekly LW loss was calculated as follows:

LW $\operatorname{loss}_{n}=\left(\mathrm{LW}_{\text {week1 }}-\mathrm{LW}_{n}\right) \times 100(\%) / \mathrm{LW}_{\text {week1 }}$

where: LW loss $_{n}$ and $\mathrm{LW}_{n}$ were respectively LW loss and LW at $n$ weeks after parturition $\mathrm{LW}_{\text {week1 }}$ was $\mathrm{LW}$ within one week after parturition.

The rate of LW loss from calving to $\mathrm{LW}_{\text {nadir }}$ was estimated in $\mathrm{kg} / \mathrm{day}$ as follows:

Rate of LW loss from calving to $L W_{\text {nadir }}=\left(L W_{\text {at calving }}-L_{W} W_{\text {nadir }}\right) /$ Number of days to reach $L W_{\text {nadir }}$.

The rate of LW gain from LW $W_{\text {nadir }}$ to 120 DIM was estimated in $\mathrm{kg} /$ day as follows:

Rate of $L W$ gain from $L W_{\text {nadir }}$ to 120 DIM $=\left(L_{\text {at } 120 \text { DIM }}-L_{\text {nadir }}\right) /\left(120-\right.$ Number of days to reach $\left.L W_{\text {nadir }}\right)$.

From day 30 postpartum, Kamar heat detectors (Kamar ${ }^{\circledR}$ Heatmount Detectors, Kamar Products Inc., Zionsville, USA) were attached to the tail-head area of cows. After a positive oestrous detection, artificial insemination (Al) was carried out after the morning or the afternoon milk session by a single trained inseminator. The Kamar detector was positive when cows showed oestrous behaviours (i.e. mucous vaginal discharge, mounting, sniffing). Kamar detectors were removed at the insemination and replaced when a following pregnancy diagnosis was negative. Pregnancy diagnoses were performed by rectal palpation by the veterinarian at 35 - 40 days after Al. Reproductive traits of dairy cows were derived from calving and Al dates following pregnancy diagnostic outcomes and were measured according to standard fertility practices.

Data were analysed using the PROC MIXED enterprise guide (SAS, 2012). The statistical model included year $(Y)$ effect, parity $(P a)$ effect, animal intake block $(B)$ effect in the trial, calving season $(S)$ effect, treatment $(T)$ effect, week $(W)$ effect of observations, interaction effects between treatment and week of observation $(W T)$, and treatment and calving season (ST) as fixed effects. The animal effect within treatments was specified as a random effect. The measured variables obtained every day within a particular week during the trial were regarded as repeated measurements of that particular week block. The statistical model was as follows:

Model $=\mu+Y_{g}+P a_{h}+B_{i}+S_{j}+T_{k}+W_{l}+(S T)_{j k}+(W T)_{k l}+\delta_{(l k) m}+\varepsilon_{i j k l m}$,

where: $\mu=$ overall mean

$Y_{g}=$ the fixed effect of the $g^{\text {th }}$ year of calving (i.e. 2014 and 2015)

$B i=$ the fixed effect of the ith animal intake block in the trial (i.e 1 to 21 )

$P a_{h}=$ the effect of the $h^{\text {th }}$ parity (i.e. primiparous and multiparous groups)

$S_{j}=$ the fixed effect of the ${ }^{\text {th }}$ season of calving (i.e. summer and winter)

$T_{k}=$ the fixed effect of the $k^{\text {th }}$ treatment (i.e. control and treatment) 
$W_{l}=$ the fixed effect of the $I^{\text {th }}$ week of observation (i.e.1 to 17)

$(S T)_{j k}=$ the interaction between levels of the $j^{\text {th }}$ season of calving and $k^{\text {th }}$ treatment

$(W T)_{k l}=$ the interaction between levels of the $t^{\text {th }}$ week of sampling and $k^{\text {th }}$ treatment

$\delta_{(k) m}=$ the variable effect of the $m^{\text {th }}$ block effect in the $k^{\text {th }}$ treatment (repeated statement)

$\varepsilon_{i j k l m}=$ the random experimental error

To avoid problems of fitting a covariance structure in the statistical model, pre- and post-partum LW data were analysed separately. All effects were used to analyse the post-partum LW, whereas the prepartum LW was analysed without the repeated statement $\left(\delta_{(k) m}\right)$ in the statistical model. The LW traits generated from LW curves (i.e. $\mathrm{LW}_{\text {nadir, }}$ number of days to reach $\mathrm{LW}_{\text {nadir }}$ ) were analysed using year, parity, blocks, calving season, treatment and the interaction between treatment and calving season as only fixed effects in the statistical model. Fertility traits were analysed using year of calving, parity, blocks, season of calving and treatment, and the interaction between treatment and season of calving as fixed effects in the statistical model. Statistical assumptions were described as fixed effects and their interactions were equal to zero with $\delta_{(k) m} \sim N\left(0, \sigma_{e}{ }^{2}\right)$ varying independently of $\varepsilon_{i j k l m}$. Differences of means and standard error (SE) of means between treatments were obtained using the pairwise comparison of the Bonferroni t-test. Significance was declared at $P<0.05$. Interactions were reported as NS (not significant) if $P>0.05$.

\section{Results and Discussion}

The effect of prepartum fibre-based diets differing in NFC and protein levels on post-partum LW and fertility traits of dairy cows is presented in Table 2.

The effects of year of calving and season of calving on LW and fertility traits of dairy cows were similar (therefore, $P$-values of their effects were not indicated in Table 2). As anticipated, pre- and post-partum LW traits of dairy cows were affected significantly by the parity effect, with mature multiparous cows (parity $>3$ ) being heavier $(P<0.05)$ than young and still growing primiparous cows. Prepartum LW of pregnant heifers and dry cows did not differ between the control and the treatment in both parity groups. The interaction between the treatment and week of observation was not significant during the prepartum period, whereas both pregnant heifers and dry cows gained LW as calving time approached (week of observation $P<0.05$, not reported in Table 2). The increase in prepartum LW in both parity groups was as expected with the increased foetal growth during the late pregnancy. Similar to the present findings, other studies reported similar LWs when cows were fed fibrebased diets that differed in fat and starch levels during the prepartum period (Grum et al., 1996; Damgaard et al., 2013). Fronk et al. (1980) studied the eight-week prepartum overconditioning of dairy cows fed $2.7 \mathrm{~kg} / \mathrm{day}$ alfalfa hay ad libitum and supplemented with $1.8 \mathrm{~kg} /$ day of grain or 6.4 to $8.2 \mathrm{~kg} /$ day grain, depending on body condition ratings. These researchers reported that feeding large amounts of grain to prepartum cows improved the digestible energy intake compared with those fed low amounts of grain, but their LW changes did not differ. Live weight improved in cows overfed energy prepartum in some studies (Douglas et al., 2006; Janovick \& Drackley, 2010), but no prepartum diet effects were observed in others (Douglas et al., 2004). The bulk of the accumulation of foetal mass (approximately $60 \%$ of a calf LW at birth) normally occurs during the last two months of the pregnancy (Bauman \& Currie, 1980). Through homeorhetic controls, the imposition of pregnancy during this period requires the specific nutrients (i.e. glucose and amino acids) that are partitioned not only for the development of the foetus, but also for the growth of the foetal membranes, the gravid uterus, and the mammary gland. In addition, Everitt (1964) reported that the foetus of a ruminant is more vulnerable to maternal undernutrition stresses than that of many other species, which impedes the normal foetal growth. Thus, maternal adaptions during late pregnancy partitioned nutrients in heifers and dry cows required for their own maternal growth and replenishment of protein and energy reserves to meet the foetal requirements (Bauman \& Currie, 1980). In this study, the lack of effects of prepartum diets differing in NFC and protein levels on the prepartum LW of heifers and dry cows can be related to the prioritization of nutrients and metabolizable energy to support the pregnancy requirements. 
Table 2 Effects of prepartum nutritional treatments that differed in non-fibre carbohydrate and protein levels on live weight and fertility traits (mean \pm SE) of dairy cows from eight weeks prepartum to 17 weeks postpartum

\begin{tabular}{|c|c|c|c|c|c|c|c|}
\hline \multirow{2}{*}{ Parameters } & \multicolumn{2}{|c|}{ Primiparous cows } & \multicolumn{2}{|c|}{ Multiparous cows } & \multicolumn{3}{|c|}{$P$ values } \\
\hline & Control & Treatment & Control & Treatment & $P a^{3}$ & $T^{3}$ & $S T^{3}$ \\
\hline Number of cows & 28 & 26 & 29 & 37 & & & \\
\hline Lactation number & 1.00 & 1.00 & $3.97 \pm 0.34$ & $3.57 \pm 0.24$ & & & \\
\hline \multicolumn{8}{|l|}{ Live weight (LW) traits } \\
\hline LW from week 8 to 1 prepartum $(\mathrm{kg})$ & $563 \pm 9$ & $570 \pm 9$ & $650 \pm 8$ & $645 \pm 6$ & $<.01$ & 0.95 & NS \\
\hline LW week 1 after calving (kg) & $525^{a} \pm 9$ & $540^{b} \pm 13$ & $600^{c} \pm 11$ & $614^{\mathrm{C}} \pm 8$ & $<.01$ & $<.01$ & NS \\
\hline $\mathrm{LW}_{\text {nadir }}(\mathrm{kg})$ & $452^{\mathrm{a}} \pm 8$ & $472^{b} \pm 13$ & $537^{c} \pm 8$ & $538^{C} \pm 8$ & $<.01$ & $<.01$ & NS \\
\hline LW loss at nadir (kg) & $68^{\mathrm{a}} \pm 5$ & $85^{b} \pm 8$ & $74^{\mathrm{ab}} \pm 7$ & $86^{b} \pm 5$ & 0.65 & 0.01 & NS \\
\hline Number of days to reach $\mathrm{LW}_{\text {nadir }}$ (day) & $35 \pm 3$ & $38 \pm 5$ & $32 \pm 2$ & $35 \pm 2$ & 0.26 & 0.30 & NS \\
\hline Rate of LW loss from calving to $L_{\text {nadir }}(\mathrm{kg} /$ day) & $2.07^{\mathrm{a}} \pm 0.17$ & $2.62^{b} \pm 0.27$ & $2.38^{\mathrm{b}} \pm 0.22$ & $2.66^{b} \pm 0.16$ & 0.31 & 0.04 & NS \\
\hline $\mathrm{LW}$ at peak $\mathrm{MY}^{1}(\mathrm{~kg})$ & $493 \pm 10$ & $517 \pm 14$ & $569 \pm 10$ & $577 \pm 9$ & $<.01$ & 0.07 & NS \\
\hline Rate of LW gain from LW nadir $_{\text {to }} 120$ DIM (kg/day) & $0.47 \pm 0.05$ & $0.49 \pm 0.08$ & $0.18 \pm 0.07$ & $0.22 \pm 0.05$ & 0.11 & 0.87 & NS \\
\hline LW at first service $(\mathrm{kg})(\mathrm{LW} \text { change in } \mathrm{kg})^{2}$ & $492 \pm 7(-33)$ & $501 \pm 11(-49)$ & $588 \pm 8(-12)$ & $577 \pm 11(-37)$ & $<.01$ & 0.86 & NS \\
\hline LW at conception $(\mathrm{kg})(\mathrm{LW} \text { change in } \mathrm{kg})^{2}$ & $501 \pm 7(-24)$ & $498 \pm 9(-52)$ & $589 \pm 8(-11)$ & $599 \pm 8(-15)$ & $<.01$ & 0.97 & NS \\
\hline LW from week 1 to 17 postpartum $(\mathrm{kg})$ & $488^{a} \pm 9$ & $507^{b} \pm 13$ & $579^{c} \pm 10$ & $579^{C} \pm 8$ & $<.01$ & $<.01$ & $<.01$ \\
\hline LW loss from week 2 to 17 postpartum (\%) & $7.65^{\mathrm{a}} \pm 1.06$ & $9.26^{b} \pm 1.13$ & $4.91^{\mathrm{C}} \pm 0.96$ & $6.13^{\mathrm{ac}} \pm 0.79$ & $<.01$ & $<.01$ & 0.01 \\
\hline \multicolumn{8}{|l|}{ Fertility traits } \\
\hline Interval from calving to first service (days) & $117^{\mathrm{a}} \pm 9$ & $86^{b} \pm 8$ & $104^{\mathrm{ab}} \pm 6$ & $99^{b} \pm 6$ & 0.90 & 0.01 & NS \\
\hline Proportion of cows serviced for the first $\mathrm{Al}^{1}$ at 80 days & $0.32 \pm 0.09$ & $0.38 \pm 0.09$ & $0.27 \pm 0.09$ & $0.35 \pm 0.08$ & 0.41 & 0.80 & NS \\
\hline Proportion of cows that were pregnant at first service & $0.25 \pm 0.08$ & $0.31 \pm 0.09$ & $0.34 \pm 0.06$ & $0.29 \pm 0.08$ & 0.89 & 0.60 & NS \\
\hline Number of services per conception & $2.34 \pm 0.32$ & $2.08 \pm 0.34$ & $2.48 \pm 0.24$ & $2.39 \pm 0.21$ & 0.29 & 0.46 & NS \\
\hline Proportion of cows that were pregnant at 120 days & $0.34 \pm 0.09$ & $0.46 \pm 0.09$ & $0.42 \pm 0.09$ & $0.38 \pm 0.08$ & 0.93 & 0.66 & NS \\
\hline
\end{tabular}

${ }^{1} \mathrm{MY}$ : milk yield, Al: artificial insemination

${ }^{2}$ Change in LW at first service (or conception) was measured as LW at calving - LW at first service (or conception)

${ }^{3} \mathrm{~Pa}$ : parity, $\mathrm{T}$ : treatment, ST: interaction ST

${ }^{a, b}$ Row means of treatments with different superscripts differ significantly at $P<0.05$ 
The prepartum nutritional effects were significant in post-partum LW and LW loss changes, LW nadir, $_{\text {, }}$

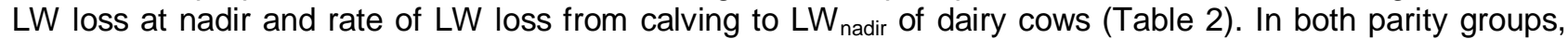
post-partum LW curves of cows decreased until the nadir in early lactation and increased afterwards. Multiparous cows in the treatment group had similar post-partum LW, LW loss at nadir and rate of LW loss from calving to $\mathrm{LW}_{\text {nadir }}$ compared with their counterparts in the control group. However, post-partum LW improved $(P<0.05)$ in the treatment compared with the control group in primiparous cows, at $507 \pm 13 \mathrm{~kg}$ and $488 \pm 9 \mathrm{~kg}$, respectively.

The LW loss change in primiparous cows was higher $(P<0.05)$ in the treatment in comparison with the control, at $9.26 \pm 1.13 \%$ and $7.65 \pm 1.06 \%$, respectively. The post-partum rate of LW loss from calving to $\mathrm{LW}_{\text {nadir }}$ of dairy cows decreased $(P<0.05)$ to $2.07 \pm 0.17 \mathrm{~kg} /$ day in cows that received an oat hay-based diet compared with $2.62 \pm 0.27 \mathrm{~kg} /$ day of their counterparts on the pTMR-based diet during the late prepartum period, respectively. Furthermore, the LW loss at nadir in primiparous cows decreased $(P<0.05)$ in the control compared with the treatment, but cows weighed $20 \mathrm{~kg}$ more $(P<0.05)$ at nadir in the treatment compared with the control group. In contrast with the current findings, previous studies in which cattle were fed various energy levels and sources in prepartum diets and a similar post-partum diet found similar postpartum LW (Grum et al., 1996; Douglas et al., 2004; 2006; Damgaard et al., 2013). Jorritsma et al. (2003) reported that a post-partum cow that undergoes continuous weight loss over time is definitely in a state of NEB, while a cow that gains weight over time is preventing the mobilization of body reserves to overcome a NEB. After the $\mathrm{LW}_{\text {nadir, }}$, cows that are maintaining or gaining LW demonstrate a positive indicator towards the process of stabilizing or improving their EB status (Van Straten et al., 2008). In the current study, the lack of effect of prepartum nutritional treatments on the post-partum LW can be attributed to the increased ability of mature multiparous cows (parity > 3) to adapt to the post-partum energy stress, compared with young and still growing primiparous cows. A possible explanation for the difference in postpartum LW in primiparous cows can be related to the positive prepartum effect of high NFC and protein levels in the pTMR-based diet, which improved the post-partum LW, compared with low levels in the oat haybased diet.

In contrast with the lack of effects on fertility traits of season of calving $(P>0.05)$, which was reported in this study (Table 2), De Rensis \& Scaramuzzi (2003) noted a decrease in the fertility of post-partum dairy cows that were inseminated in the summer, compared with those that were inseminated in winter. Pennington et al. (1985) reported that heat stress in dairy cows decreased the duration and intensity of oestrous activity, leading to a decrease in the number of mounts in hot weather compared with cold weather and, consequently, poor detection of oestrus. Supporting these arguments, fertility functions were reported to be disrupted as dairy cows are not comfortable during sudden and prolonged heat stress conditions in the Mediterranean summer (Kadzere et al., 2002). These thermal disruptions then affect hormonal balances, ovarian function, oestrous expression, oocyte health, conception, embryonic development and pregnancy survival of dairy cows. The lack of effect of season of calving on fertility traits was possibly related to the low number of animals used in this study, which masked this effect.

In the current study (Table 2), no prepartum diet effects $(P>0.05)$ were recorded between control and treatment groups in both parity groups regarding the proportion of cows serviced for the first time within the first 80 DIM, pregnancy rates at first service, number of services per conception, and cow LW at first service and at conception. However, the CFS interval of dairy cows was affected significantly by the prepartum diet effect. Numbers of days from calving to first service were similar in multiparous cows, being $104 \pm 6$ and $99 \pm 6$ for control and treatment groups, respectively. Primiparous cows in the control group had a larger CFS interval $(P<0.05)$ compared with their counterparts in the treatment group, namely $117 \pm 9$ and $86 \pm 8$ days, respectively. Butler \& Smith (1989) reported that early resumption of oestrus in dairy cows allowed them to complete one or more oestrus cycles before breeding. Moreover, an early ovarian cyclicity in postpartum cows was reported to be associated with an improved conception rate (Butler, 2000; Galvao et al., 2010), as these cows are more likely to have normal oestrous cycle lengths and more pronounced oestrous behaviours during the breeding period (Roche, 2006). However, the significant shortening in the CFS interval for the primiparous group in the treatment did not affect the proportion of cows that were pregnant at 120 DIM in the current study compared with those in the control, that is, $0.46 \pm 0.09$ and $0.34 \pm 0.09$, respectively. Similarly, their multiparous counterparts showed no post-partum differences in the proportion of cows that were pregnant at 120 DIM between treatment and the control, that is, $0.38 \pm 0.08$ and $0.42 \pm 0.09$, respectively. Other investigations found that prepartum diets that differed in energy levels and sources did not affect the CFS interval and proportions of cows that were pregnant in the subsequent lactation (Pushpakumara et al., 2003; McNamara et al., 2003; Burke et al., 2010). In contrast, increasing dietary fat in prepartum diets from $2.9 \%$ to $4.9 \%$ with granular long chain saturated fatty acids improved the pregnancy rate at 220 DIM from 58\% to $86 \%$ (Frajblat \& Butler, 2003). Cavestany et al. (2009) found that the proportions of grazing cows that ovulated from the first dominant follicle postpartum were similar when fed 
prepartum diets consisting of low (5.2 kg of whole-plant wheat silage on DM basis/day) versus high (3.6 kg of wheat bran $+0.012 \mathrm{~kg}$ of urea $+4.7 \mathrm{~kg}$ corn silage, on DM basis/day) levels of concentrates in both parity groups. However, the interval from calving to first ovulation in the same study decreased in cows that received high levels of supplements versus low in the multiparous cows. Castro et al. (2012) studied the effect of the metabolic and energy status during the DP on the post-partum resumption of ovarian activity in dairy cows, using messenger ribonucleic acid (RNA) abundance of various gluconeogenic enzymes and metabolic hormones in the liver. These researchers found that the post-partum ovarian function in cows was negatively affected by the low prepartum energy status, as was evident in low levels of glucose, insulin, insulin-like growth factor I (IGF-I) and thyroxine. Furthermore, the prepartum energy status was reflected in post-partum anovulatory cows by declines over time in hepatic messenger RNA abundance of metabolic factors such as I-R, PC and PEPCKm (Insulin receptor, pyruvate carboxylase and phosphoenolpyruvate carboxykinase-mitochondrial, respectively). Using a Cox proportional hazard model on the data of seven experiments from 1993 to 2010, Cardoso et al. (2013) investigated the effect of prepartum energy levels (low: limited net energy lactation $\left(\mathrm{NE}_{\mathrm{L}}\right)$ intake to $\leq 100 \%$ of requirement versus high: $\mathrm{NE}_{\mathrm{L}}$ intake to $>100 \%$ of requirement) on reproductive performance in dairy cows in the subsequent lactation. These researchers found that cows fed a prepartum low energy diet during the close up DP prevented the mobilization of body reserves and increased $N_{L}$ intake during the first four weeks after calving. These post-partum biological responses in the same study resulted in reduced hepatic fat deposition and decreased days open compared with those on prepartum high energy diet.

Dairy heifers usually calve for the first time around 24 months old, making them physically immature at this age (Coffey et al., 2006). Pregnant heifers need nutrients for their own growth in addition to that of the developing calf before calving and milk synthesis after calving (Wathes et al., 2007; McArt et al., 2013), making them more vulnerable to the periparturient NEB compared with multiparous cows. Normally, the NEB commences a few days before parturition reaches a NEB nadir two to four weeks postpartum, and the EB becomes positive again by 10 to 12 weeks after calving (Butler, 2003). Additionally, a carry-over effect of the NEB status suppresses the luteinizing hormone (LH) surge and decreases ovarian responsiveness to $\mathrm{LH}$ stimulation (Beam \& Butler, 1999; Butler, 2000; Thatcher, 2017), both of which result in delays in the resumption of cyclicity (Butler et al., 2006; Giuliodori et al., 2011), reduced oestrous expression (Lopez et al., 2004) and diminished viability and quality of the ovulating follicle (Lucy et al., 1991). A possible explanation for differing post-partum CFS intervals in primiparous cows can be related to the ability of the prepartum pTMR-based diet to significantly replenish post-partum LW, indicating improvements in EB and nutritional status, compared with the prepartum oat hay-based diet (Table 2). In multiparous cows (parity $>3$ ), the lack of effect of prepartum nutritional treatments on the post-partum CFS interval can be attributed to the increased hepatic adaptation to post-partum energy stress, compared with young and still growing primiparous cows. The lack of differences in pregnancy rates at 120 DIM in both parity groups can be related to the prepartum feeding period used in the current trial, compared with a conventional DP of 56 to 60 days. The prepartum period used in this study had possibly not been sufficient to encourage post-partum metabolic and hormonal responses that improve the conception success in dairy cows in the subsequent lactation.

\section{Conclusion}

In this study, primiparous cows that were maintained on prepartum pTMR-based diet that contained high NFC and CP levels significantly replenished the LW and shortened the interval CFS in the subsequent lactation compared with their counterparts on a prepartum oat hay-based diet consisting of low NFC and CP levels. However, the proportions of cows that were pregnant at 120 DIM in the subsequent lactation were similar between the two prepartum fibre-based diets in both parity groups. Different prepartum feeding periods and nutritional strategies that involve various types and levels of energy and protein nutrients to stimulate post-partum metabolic and hormonal responses that benefit fertility warrant further investigation.

\section{Acknowledgements}

The authors express gratitude to the Western Cape Department of Agriculture (WCDA) for permission to use the facilities and data towards a PhD study for Mr Useni at the University of Stellenbosch. The support of the workers and management at the dairy section of the Elsenburg Research Farm is also greatly appreciated. This study was funded by the Western Cape Agricultural Research Trust (WCART) with technical support from the WCDA. Mr Useni acknowledges the financial support from the WCART towards his PhD studies.

\section{Authors' Contributions}

Conception and design of the trial: BAU and CJCM; data collection and analysis: BAU; drafting of paper: BAU; critical revision: CJCM; final approval of version to be published: CWC. 


\section{Conflict of Interest Declaration}

The authors certify that they have no affiliations with any organisation or entity with any financial or non-financial interest in the subject matter or materials discussed in this manuscript.

\section{References}

Alawneh, J.I., Stevenson, M.A., Williamson, N.B., Lopez-Villalobos, N. \& Otley, T., 2012. The effect of live weight change on reproductive performance in a seasonally calving, pasture fed dairy herd. Livest. Prod. 145, 131-139.

AOAC, 1990. Official methods of analysis, 14th ed. Association of Official Analytical Chemists, Washington, DC, USA.

Bauman D.E. \& Currie, W.B., 1980. Partitioning of nutrients during pregnancy and lactation: A review of mechanisms involving homeostasis and homeorhesis. J. Dairy Sci. 63, 1514-1529.

Beam, S.W. \& Butler, W.R., 1999. Effects of energy balance on follicular development and first ovulation in postpartum dairy cows. J. Reprod. Fertil. 54, 411-424.

Beever, D.E., 2006. The impact of controlled nutrition during the dry period on dairy cow health, fertility and performance. Anim. Reprod. Sci. 96, 212-226.

Burke, C.R., Kay, J.K., Phyn, C.V.C., Meier, S., Lee, J.M. \& Roche, J.R., 2010. Short communication: Effects of dietary non-structural carbohydrates prepartum and postpartum on reproduction of grazing dairy cows. J. Dairy Sci. 93 , $4292-4296$.

Butler, S.T., Pelton, S.H. \& Butler, W.R., 2006. Energy balance, metabolic status and first postpartum ovarian follicle wave in cows administered propylene glycol. J. Dairy Sci. 89, 2938-2951.

Butler, W.R., 2000. Nutritional interactions with reproductive performance in dairy cattle. Anim. Reprod. Sci. 60-61, 449-457.

Butler, W.R., 2003. Energy balance relationships with follicular development, ovulation and fertility in postpartum dairy cows. Livest. Prod. Sci. 83, 211-218.

Butler, W.R. \& Smith, R.D., 1989. Interrelationship between energy balance and postpartum reproductive function in dairy cattle. J. Dairy Sci. 72, 767-783.

Cardoso, F.C., Leblanc, S.J., Murphy, M.R. \& Drackley, J.K., 2013. Prepartum nutritional strategy affects reproductive performance in dairy cows. J. Dairy Sci. 96, 5859-5871.

Castro, N., Kawashima, C., Van Dorland, H.A., Morel, I., Miyamoto, A. \& Bruckmaier, R.M., 2012. Metabolic and energy status during the dry period is crucial for the resumption of ovarian activity postpartum in dairy cows. J. Dairy Sci. 95, 5804-5812.

Cavestany, D., Viñoles, C., Crowe, M.A., La Manna, A. \& Mendoza, A., 2009. Effect of prepartum diet on postpartum ovarian activity in Holstein cows in a pasture-based dairy system. Anim. Reprod. Sci. 114, 1-13.

Coffey, M.P., Hickey, J. \& Brotherstone, S., 2006. Genetic aspects of growth of Holstein-Friesian dairy cows from birth to maturity. J. Dairy Sci. 89, 322-329.

Damgaard, D.M., Weisbjerg, M.R. \& Larsen, T., 2013. Priming the cow lactation by rapeseed supplementation in the dry period. J. Dairy Sci. 96, 3652-3661.

De Rensis, F. \& Scaramuzzi, R.J., 2003. Heat stress and seasonal effects on reproduction in the dairy cow: A review. Theriogenology 60, 1139-1151.

Drackley, J.K., Wallace, R.L., Graugnard, D., Vasquez, J., Richards, B.F. \& Loor, J.J., 2014. Visceral adipose tissue mass in non-lactating dairy cows fed diets differing in energy density. J. Dairy Sci. 97, 3420-3430.

Douglas, G.N., Overton, T.R., Bateman II, H.G. \& Drackley, J.K., 2004. Peripartal metabolism and production and production of Holstein cows fed diets supplemented with fat during the dry period. J. Dairy Sci. 87, 4210-4220.

Douglas, G.N., Overton, T.R., Bateman II, H.G., Dann, H.M. \& Drackley, J.K., 2006. Prepartal plane of nutrition, regardless of dietary energy source, affects periparturient metabolism and dry matter intake in Holstein cows. J. Dairy Sci. 89, 2141-2157.

Duffield, T.F., Lissemore, K.D., McBride, B.W. \& Leslie, K.E., 2009. Impact of hyperketonemia in early lactation dairy cows on health and production. J. Dairy Sci. 92, 571-580.

Everitt, G.C., 1964. Maternal undernutrition and retarded foetal development in Merino sheep. Nature 201, $1341-1342$.

Frajblat, M. \& Butler, W.R., 2003. Effect of dietary fat prepartum of first ovulation and reproductive performance in lactating dairy cows. J. Dairy Sci. 86 (Suppl. 1), 119 (Abstract).

Fronk, T.J., Schultz, L.H. \& Hardie, A.R., 1980. Effect of dry period overconditioning on subsequent metabolic disorders and performance of dairy cows. J. Dairy Sci. 63, 1080-1090.

Galvao, K.N., Frajblat, M., Butler, W.R., Brittin, S.B., Guard, C.L. \& Gilbert, R.O., 2010. Effect of early postpartum ovulation on fertility in dairy cows. Reprod. Dom. Anim. 45, E207-E211.

Giron, H.C., 1973. Comparison between dry ashing and wet digestion in the preparation of plant material for atomic absorption analysis. Atom. Absorpt. Newsl. 12, 28-29.

Giuliodori, M.J., Delavaud, C., Chilliard, Y., Becú-Villalobos, D., Lacau-Mengido, I. \& De la Sota, R.L., 2011. High NEFA concentrations around parturition are associated with delayed ovulations in grazing dairy cows. Livest. Sci. 141, 123-128.

Grum, D.E., Drackley, J.K., Younker, D.W., Lacount, D.W. \& Veenhuizen, J.J., 1996. Nutrition during dry period and hepatic lipid metabolism of periparturient dairy cows. J. Dairy Sci. 79, 1850-1864.

Janovick, N.A., Boisclair, Y.R. \& Drackley, J.K., 2011. Prepartum dietary energy intake affects metabolism and health during the periparturient period in primiparous and multiparous Holstein cows J. Dairy Sci. 94, 1385-1400.

Janovick, N.A. \& Drackley, J.K., 2010. Prepartum dietary management of energy intake affects postpartum intake and lactation performance by primiparous and multiparous Holstein cows. J. Dairy Sci. 93, 3086-3102. 
Jorritsma, R., Wensing, T., Kruip, T.A., Vos, P.L. \& Noordhuizen, J.P., 2003. Metabolic changes in early lactation and impaired reproductive performance in dairy cows. Vet. Res. 34, 11-26.

Jouany, J.P., 2006. Optimizing rumen functions in the close-up transition period and early lactation to drive dry matter intake and energy balance in cows. Anim. Reprod. Sci. 96, 250-264.

Kadzere, C.T., Murphy, M.R., Silanikove, N. \& Maltz, E., 2002. Heat stress in lactating dairy cows: A review. Livest. Prod. Sci. 77, 59-91.

Lopez, H., Satter, L.D. \& Wiltbank, M.C., 2004. Relationship between level of milk production and oestrous behaviour of lactating dairy cows. Anim. Reprod. Sci. 81, 209-223.

Lucy, M.C., Staples, C.R., Michel, F.M. \& Thatcher, W.W., 1991. Energy balance and size and number of ovarian follicles detected by ultrasonography in early postpartum dairy cows. J. Dairy Sci. 74, 473-482.

McArt, J.A., Nydam, D.V, Oetzel, G.R., Overton, T.R. \& Ospina, P.A., 2013. Elevated non-esterified fatty acids and $\beta$-hydroxybutyrate and their association with transition dairy cow performance. Vet. J. 198, 560-570.

McNamara, S., Murphy, J.J., Rath, M. \& O'Mara, F.P., 2003. Effects of different transition diets on energy balance, blood metabolites and reproductive performance in dairy cows. Livest. Prod. Sci. 84, 195-206.

National Research Council (NRC), 2001. Nutrient requirements of dairy cattle. $7^{\text {th }}$ rev. ed. National Academy Press, Washington, DC, USA.

Olsson, G., Emanuelson, M. \& Wiktorsson, H., 1998. Effects of different nutritional levels prepartum on the subsequent performance of dairy cows. Livest. Prod. Sci. 53, 279-290.

Pennington, J.A., Albright, J.L., Diekman, M.A. \& Callahan, C.J., 1985. Sexual activity of Holstein cows: Seasonal effects. J. Dairy Sci. 68, 3023-3027.

Pushpakumara, P.G.A., Gardner, N.H., Reynolds, C.K., Beever, D.E. \& Wathes D.C., 2003. Relationships between transition period diet, metabolic parameters and fertility in lactating dairy cows. Theriogenology 60, 1165-1185.

Rabelo, E., Rezende, R.L., Bertics, S.J. \& Grummer, 2005. Effects of prepartum and postfresh transition diets varying in dietary energy density on metabolic status of periparturient dairy cows. J. Dairy Sci. 88, 4375-4383.

Roche, J.F., 2006. The effect of nutritional management of the dairy cow on reproductive efficiency. Anim. Reprod. Sci. 96, 282-296.

Rukkwamsuk, T., Wensing, T. \& Geelen, M.J.H., 1999. Effect of overfeeding during the dry period on the rate of esterification in adipose tissue of dairy cows during the periparturient dairy cows. J. Dairy Sci. 82, 1164-1169.

Sakaguchi, M., 2009. Differences between body condition scores and body weight changes in postpartum dairy cows in relation to parity and reproduction indices. Can. Vet. J. 50, 649-653.

SAS, 2012. Statistical Analysis Systems (SAS Enterprise guide Software, Version 5.1). SAS Institute Inc., Cary, North Carolina, USA.

Thatcher, W.W., 2017. A 100-year review: Historical development of female reproductive physiology in dairy cattle. J. Dairy Sci. 100, 10272-10291.

Van Soest, P.J., Robertson, J.B. \& Lewis, B.A., 1991. Methods for dietary fibre, neutral detergent fibre and non-starch polysaccharides in relation to animal nutrition. J. Dairy Sci. 74, 3583-3597.

Van Straten, M., Shpigel, N.Y. \& Friger, M., 2008. Analysis of daily body weight of high-producing dairy cows in the first one hundred twenty days of lactation and associations with ovarian inactivity. J. Dairy Sci. 91, 3353-3362.

Wankhade, P.R., Manimaran, A., Kumaresan, A., Jeyakumar, S., Ramesha, K.P., Sejian, V., Rajendran, D. \& Varghese, M.R., 2017. Metabolic and immunological changes in transition dairy cows: A review. Vet. World 10, 1367-1377.

Wathes, D.C., Cheng, Z., Bourne, N., Taylor, V.J., Coffey, M.P. \& Brotherstone, S., 2007. Differences between primiparous and multiparous dairy cows in the inter-relationships between metabolic traits, milk yield and body condition score in the periparturient period. Domest. Anim. Endocrinol. 33, 203-225. 